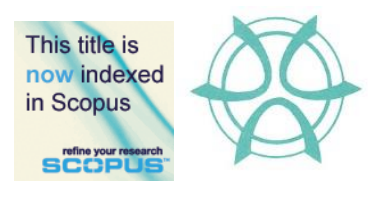

PLANNING MALAYSIA:

Journal of the Malaysian Institute of Planners

VOLUME 16 ISSUE 2 (2018), Page 197 - 206

\title{
THE MEDIATING EFFECTS OF AWARENESS ON THE RELATIONSHIP BETWEEN PROCUREMENT MANUAL COMPLIANCE'S BARRIERS AND COST PERFORMANCE OF CONSTRUCTION PROJECTS
}

\author{
Abdullahi Nafiu Zadawa ${ }^{1}$, Abdul Aziz Hussin ${ }^{2}$ \& Atasya Osmadi ${ }^{3}$ \\ ${ }^{1}$ School of Environmental Technology \\ ABUBAKAR TAFAWA BALEWA UNIVERSITY NIGERIA \\ ${ }^{2,3}$ School of Housing Building and Planning \\ UNIVERSITI SAINS MALAYSIA
}

\begin{abstract}
Public Procurement Manual (PPM) are the procedural guidelines for executing public procurement practices including construction procurement. Compliance with PPM among construction procurement parties has been facing serious challenges which affects the performance of construction projects especially cost aspect. This study identified fraudulent practices as the major procurement manual compliances' barriers affecting cost performance of construction projects. The paper examines the mediating effects of awareness on procurement manual compliance's barriers affecting cost performance. Data was collected from the procurement entities of nine selected Nigerian federal universities. A mediation analysis was performed via bias-corrected bootstrapped confidence interval approach using Process Macro package. The indirect effects obtained was positive and different from zero, and the confidence interval within which the effect occur do not include zero indicating that awareness can mitigate the effects of fraudulent practices been compliance barriers affecting cost performance of construction projects.
\end{abstract}

Keywords: awareness, public procurement manual, non-compliance, cost performance 
Abdullahi Nafiu Zadawa, Abdul Aziz Hussin, \& Atasya Osmad

The Mediating Effects of Awareness on The Relationship Between Procurement Manual Compliance's Barriers and Cost

Performance of Construction Projects

\section{INTRODUCTION}

Public procurement manuals (PPM) are the procedural guidelines for executing procurement of major infrastructural facilities, construction of building projects, supply of goods and services by the public entities. The manuals are meant to ensure the attainment of principles of public procurement mainly accountability, transparency, competition, and fairness among tendering bidders. In most developing countries procurement manuals are highlighted within the public procurement policies. Most of the country's procurement policies are the dividends of public reforms initiatives for sustainable development of infrastructural facilities (Williams-Elegbe, 2013). Despite the expected role played by the procurement manual in regulating public procurement conducts, compliance with the manual among construction procurement stakeholders and project parties have been facing serious snags (Jibrin, Ejura, \& Augustine, 2014).

Gelderman, Ghijsen and Brugman (2006) reported issues of noncompliance with the European Union (EU) tendering and procurement directives. Among OECD member countries, application of procurement proceedings remained seldom in certain economic sectors (OECD, 2007). In Malaysia, an interview with contractors revealed cases with inappropriate application of procurement manuals (Hui, Radiah, Normah, Rashidah, \& Nurul, 2011). In Nigeria, indications of selective implementation and non-compliance with PPM is evidenced in most economic sectors of the country (Ojo \& Gbadebo, 2014). In the construction industry in particular, one of the major barriers to compliance with the PPM is fraudulent practices especially at the pre-construction contract stages (Wells, 2013; Shehu, 2014). In order to further understand these literature arguments, this paper attempts to explore the situations under which compliance with PPM will reduce the negative effects of fraudulent practices affecting cost performance of construction projects. This paper examines the mediating effects of awareness on the relationship between PPM non-compliance barriers and cost performance of construction projects.

\section{LITERATURE REVIEW}

This section of the paper presents a review of the literature on the study variables which leads to hypothesis development aimed at examining a mediation-based causal relationship of awareness on procurement manual compliance barriers that affect cost performance. A hypothetical mediation framework of the study is also presented at the tail of this section.

\section{Public Procurement Manual and Related Compliance Issues}

Public procurement manuals (PPM) are the regulatory procedural guidelines for executing construction contracts and a host of other public procurement practices. Construction procurement as the major activities of the construction industry is a 
PLANNING MALAYSIA

Journal of the Malaysia Institute of Planners (2018)

sub-element of public procurement which contributes immensely to the development of every nation (Inuwa \& Diang'a, 2015; Abdullahi, Hussin, \& Osmadi, 2015). In most developing countries and especially in Nigeria, the PPM plays a vital role in ensuring the delivery of construction projects based on the specification, time and financial budget (Ojo \& Gbadebo, 2014; Shehu, 2014). Globally non-compliance to procurement directives seems to be an issue. Previous studies that attempted to investigate compliance with procurement manuals' issues are delimited to the provision of compliance factors that determines construction project cost performances. Yet from the construction industry perspective, compliance with the PPM among major procurement stakeholders and projects parties are facing serious challenges (Ojo \& Gbadebo, 2014; Abdullahi, Hussin, \& Osmadi, 2017). Fraudulent practices especially at pre-contract and tendering stages are one of the barriers to compliance with PPM among stakeholders (Wells, 2013; Shehu, 2014). This study identified fraudulent practices factors in construction procurement as the major barriers to the compliance with PPM, hence it is the main dimension of the independent variable of the study. The cost performance of construction projects is the dependent variable.

\section{$H_{1}$ : Public Procurement Manual Compliance's Barriers affects Cost Performance of Construction Projects.}

\section{The Mediating Effects of Awareness}

Awareness is the mediating variable of the study. Awareness is hypothesized to mitigate the effects of the relationship between PPM compliance's barriers (fraudulent practices) and cost performance of construction projects. Lack of awareness has created a wide void in the race towards reforming public procurement sector, thus providing appropriate knowledge through training and enlightening the procurement stakeholders would be an effective tool (Gelderman et. al., 2006). Findings of prior studies indicated that compliance with procurement manual is influenced directly by the level of familiarity among the stakeholders, and realistic level of familiarity is achieved with sufficient awareness (Boer \& Telgen, 1998; Lazarides, 2011). Mbaya (2013) also maintained that advancing the level of awareness will be the most effective tool to appropriately educate procurement stakeholders, professional and other relevant construction project parties towards improving compliance. In their studies, Hui et al. (2011) also recommended awareness as an ultimate remedy to non-compliance among construction project parties. Sang and Mugambi (2014) also affirmed that awareness is the most significant compliance factor compared to other compliance measurement items. 
Abdullahi Nafiu Zadawa, Abdul Aziz Hussin, \& Atasya Osmad

The Mediating Effects of Awareness on The Relationship Between Procurement Manual Compliance's Barriers and Cost

Performance of Construction Projects

H2: Awareness mediates the effects of the relationship between Public Procurement Manual compliance barriers and cost performance of construction projects.

\section{Construction Project Cost Performance}

Cost is one of the most sensitive core elements that determine the overall performance of construction projects (Akinsiku \& Iyagba, 2014). The role played by cost in construction project procurements runs through the entire project management life cycle (Azhar, Farooqui, \& Ahmed, 2008; Othman, Zakaria, Nordin, Shahidan, \& Jusoff 2010). Therefore, projects executed within appropriate budget is said to satisfy the basic performance requirement; thus it fulfills the client's need of good value for money and achieve technical performance based on specification (Frimpong, Oluwoye, \& Crawford, 2003). Hitherto, cost performance aspect of construction projects remains one of the major challenge of the construction industry. Inadequate knowledge of the procurement manual due to lack of awareness is considered as a foremost cause (Abdullahi et. al., 2017; Akinsiku \& Iyagba, 2014).

\section{Conceptual Mediation Framework of the Study}

Figure 1 below presents the conceptual mediation framework of the study; figure 1a shows the total effects path, while figure $1 \mathrm{~b}$ shows the indirect/mediation effects paths.

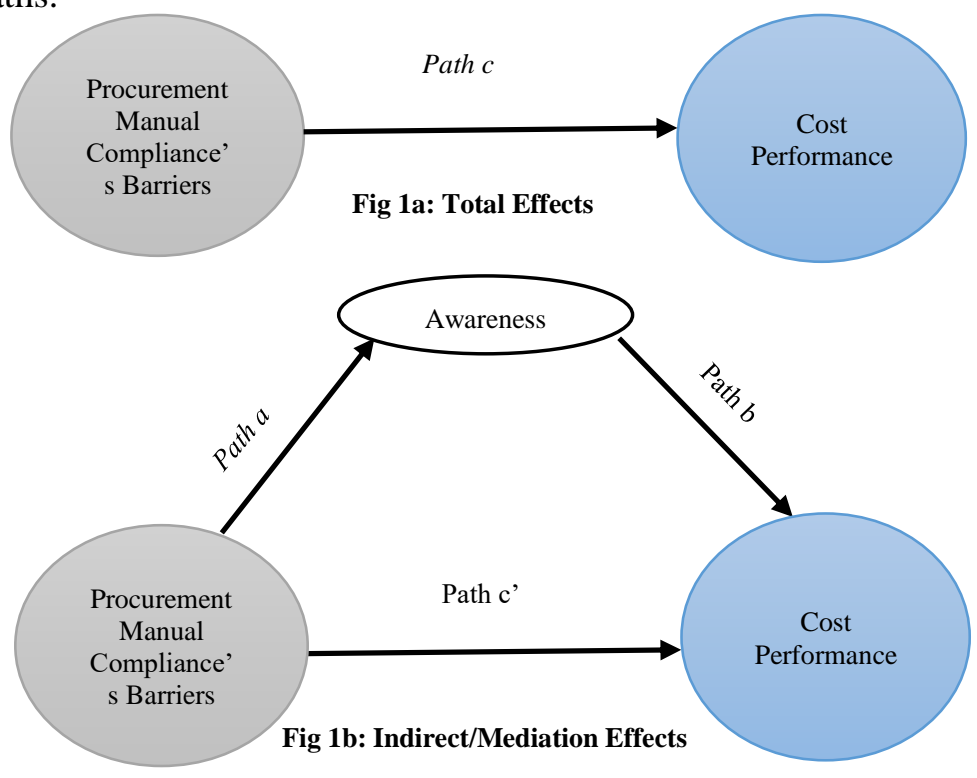

Figure 1: Conceptual Mediation Framework of the Study 
PLANNING MALAYSIA

Journal of the Malaysia Institute of Planners (2018)

\section{RESEARCH METHODS}

The study uses quantitative strategy to examine the mediation effects of awareness between public procurement guidelines compliance barriers and cost performance of construction projects. Quantitative research strategy allows the variables to be tested with the help of theories so that an appropriate outcome can be obtained (Sekaran \& Bougie, 2016). The study populations are construction project parties attached to the federal universities in Nigeria, mainly the project client, project managers, professional consultants, and contractor. Stratified proportionate random sampling was used in selecting adequate number of sample. The study was limited to twenty-two federal universities across the northern Nigeria, with a total of 1870 active procurement stakeholders and construction project parties. Nine (9) universities were randomly selected out of which 320 respondents were selected based on Krejcie and Morgan (1970) sampling technique as cited in Sekaran \& Bougie, (2016). The structured survey questionnaire was the main instrument used in collecting data. It was designed and tested for validity and reliability (Sakaran \& Bougie, 2016). All the items were measured with 5-point Likert scale; 1 for strongly disagree and 5 for strongly agree. The Likert scale has the proficiency to ensure all items and factors measured the same thing (Cornalba\& Giudici, 2004). 540 questionnaires were distributed randomly to the targeted respondents Only 410 copies were retrieved, 31 were rejected, and the remaining 379 useable questionnaires were analyzed, implying a $70 \%$ and $76 \%$ response rate and return rates respectively.

\section{RESULTS PRESENTATION}

Mediation analysis was performed based on Bias-corrected bootstrapping confidence interval approach using Process Macro developed by Hayes (2012). Bootstrapping methods are non-parametric based statistics that perform mediation analysis by the means of resampling and replacement. In particular, bias-corrected bootstrapped confidence interval method has an advantage of high statistical power and it does not rely on normal theory assumption (Preacher \& Hayes, 2008).

\section{Effects of Compliance's Barriers on Awareness (path a)}

Coefficient of determination along path $a$ obtained was 1.4511 , t-value was 84.2227 , while $\mathrm{p}$-value was 0.0000 significant $(\mathrm{p}<0.05)$ at $95 \%$ confidence interval. The lower and upper levels confidence intervals (i.e. LLCI and ULCI) were 1.3919 and 1.5103 respectively as presented in table 1 below. Thus, p-value obtained ( $\mathrm{p}<0.05$ ) and the LLCI and ULCI (which do not include zero) indicated statistical significant relationship along path- $a$ based on bootstrapped confidence interval mediation requirements (Hayes, 2013; Williams-Elegbe, 2013). 
Abdullahi Nafiu Zadawa, Abdul Aziz Hussin, \& Atasya Osmad

The Mediating Effects of Awareness on The Relationship Between Procurement Manual Compliance's Barriers and Cost

Performance of Construction Projects

\section{Effects of the Relationship along path $b$ and path c'}

Table 1 also presents the coefficient of determination along both path $b$ and path $c^{\prime}$. The effects of awareness on cost performance (path $b$ ) had a coefficient of 0.2755 , t-value is 17.9927 , while p-value is $0.0000(\mathrm{p}<0.05)$ which is significant at $95 \%$ bias corrected bootstrapped confidence interval. The ULCI and LLCI along path $b$ were 0.2454 and 0.3056 respectively, path $\mathrm{b}$ is also significant since there was no zero value between the confidence interval and p-value $<0.05$ at 95 (Hayes, 2013; Zhao et. al., 2010). Path c' had a coefficient of -0.0526 , t-value was -1.4673 and $p$-value was 0.1431 insignificance $(p>0.05)$ at $95 \%$ biascorrected bootstrapped confidence interval. The ULCI and LLCI were -0.1232 and 0.0178 respectively. Hence, the p-value was not significant and zero (0) value was included within the ULCI and LLCI indicating insignificant effects along path c' (Hayes, 2013; Zhao, Lynch, \& Chen, 2010).

\section{Total Effects of Compliance Barriers on Cost Performance (path c)}

Coefficient of determination of the total effects path (path c) was $0.3730, \mathrm{t}$-value was 23.3569 while $\mathrm{p}$-value was 0.0000 significant $(\mathrm{p}<0.05)$. The ULCI and LLCI were 0.3416 and 0.4044 respectively which obviously did not include zero within the range indicating statistical significant effects along path $c$ based on bias-corrected bootstrapped confidence interval mediation principles (Hayes, 2013; Zhao et. al., 2010).

Table 1: Summary of the Mediation Results along various Paths

\begin{tabular}{lccccc}
\hline $\begin{array}{l}\text { Variables } \\
\text { Linkages }\end{array}$ & $\begin{array}{c}\text { Coeff. of } \\
\text { Determin } \\
\text { ation }\end{array}$ & P-Values & $\begin{array}{c}\text { LLCI \& } \\
\text { ULCI }\end{array}$ & Path & Remark \\
\hline $\begin{array}{l}\text { Complcs' bar. to } \\
\text { Awareness }\end{array}$ & 1.4511 & 0.0000 & $\begin{array}{c}1.3919, \\
1.5103\end{array}$ & Path $a$ & Sig \\
$\begin{array}{l}\text { Awareness. to } \\
\text { CstPerf }\end{array}$ & 0.2755 & 0.0000 & $\begin{array}{c}0.2454, \\
0.3056\end{array}$ & Path $b$ & Sig \\
$\begin{array}{l}\text { Complcs' bar. to } \\
\text { CstPerf via }\end{array}$ & -0.0526 & 0.1431 & $\begin{array}{c}-0.1232, \\
\text { Path c }\end{array}$ & In sig. \\
$\begin{array}{l}\text { Awareness } \\
\text { Complcs's bar. to }\end{array}$ & 0.3730 & 0.0179 & & \\
CstPerf & & & 0.3416, & Path c & Sig \\
\hline
\end{tabular}

\section{DISCUSSION}

In accordance with bias-corrected bootstrapped confidence interval method, the mediation effect was evaluated based on the indirect effects' paths (i.e. path a \& path b) as recommended by Hayes, Preacher and Myers, (2011). This approach mainly for the contemporary mediation methods such as bootstrapping was 
introduced to overcome the weakness of the famous Baron and Kenny (1986) causal step mediation approach.

Mathematically, the indirect effect is the product of the indirect effect path's coefficients

i.e. $($ path $a *$ path $b)$

$1.4511 * 0.2755=0.3997$

The indirect effects (0.3997), which was estimated based on the coefficients of the determination of the effects of PPM compliance's barriers on awareness (i.e. path $a=0.2755$ ) as well as that of path $b=0.3997$ which was the effects of awareness on cost performance of construction projects. As shown the indirect effects (0.3997) was positive and totally different from zero, thus indicating the occurrence of mediation in the hypothesis framework of the study as suggested by Hayes, (2012), Hayes, (2009) as well as MacKinnon, Lockwood and Williams (2004). Therefore, the findings signified that awareness mitigated the negative effects of the barriers to compliance with public procurement manual (mainly fraudulent practices) on cost performance of construction projects. Figure 2 shows the final derived mediation-based framework of the study indicating coefficients of determinations along the various paths.

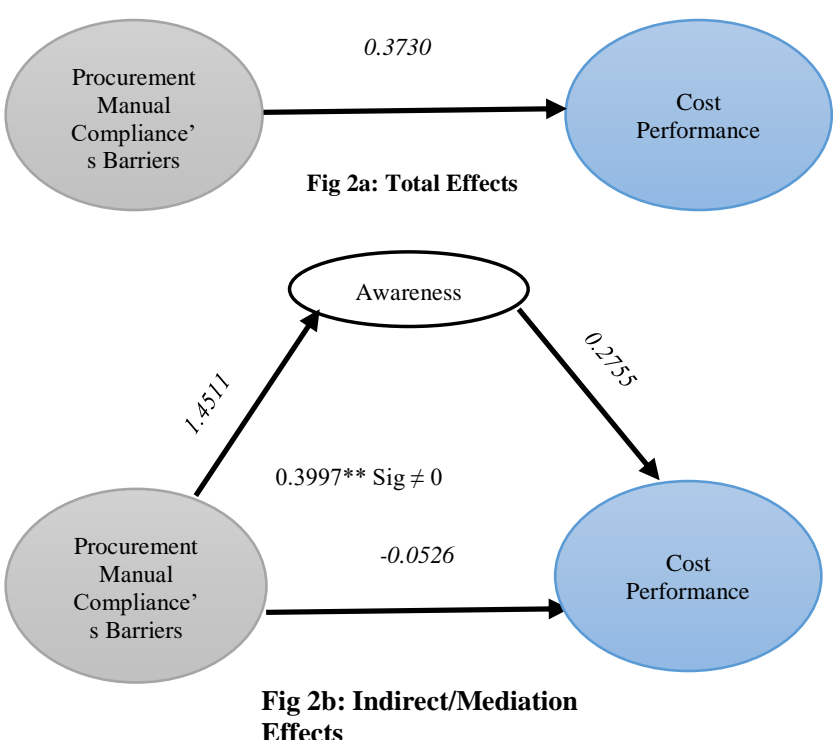

Figure 2: Derived mediation framework of the study

\section{CONCLUSION \& RECOMMENDATION}

This study aims to examine the mediating effects of awareness on the relationship between PPM compliance barriers and cost performance of construction projects. 
Abdullahi Nafiu Zadawa, Abdul Aziz Hussin, \& Atasya Osmad

The Mediating Effects of Awareness on The Relationship Between Procurement Manual Compliance's Barriers and Cost

Performance of Construction Projects

Data was collected from procurement entities of Nigerian federal universities, analysis was performed through bias-corrected bootstrapped confidence interval mediation approach using Process Macro. The indirect effects obtained which determines the occurrence of the mediation effects was positive and different from zero, also the bias-corrected confidence interval within which the indirect or mediation effects occur do not include zero. This signifies that, awareness proposed as a mediating variable will mitigate the large negative effects of PPM compliance barriers (fraudulent practices) on cost performance of construction projects. These findings conform to Kisang and Kwasira (2005), and Onyinkwa (2013). The study has contributed to the body of knowledge to the practices of construction project procurement. The study recommends that procurement entities should widen the level of awareness on the appropriate application of public procurement manual in order to improve compliance among major stakeholders and construction project parties.

\section{REFERENCES}

Abdullahi, N. Z., Hussin, A. A., \& Osmadi, A. (2015). Determinants of compliance with public procurement guidelines in the Nigerian construction industry. Jurnal Teknologi, 75(9), 107-110.

Abdullahi, N. Z., Hussin, A. A., \& Osmadi, A. (2017). Mediation effects of innovative procurement practices between the determinants of non-compliance with public procurement guidelines and construction project cost performance in the Nigerian construction industry. Transactions on Ecology and the Environment, 210, 99-109.

Akinsiku, O. E. \& Iyagba, O. A. (2014). Cost and time performance of construction projects: A comparative study of southern Peninsular Malaysia and Lagos, Nigeria. Journal of Education Research, 2(2), 75-82.

Azhar, N., Farooqui, R. U. \& Ahmed, S.M. (2008, August). Cost overrun factors in construction industry of Pakistan. $1^{\text {st }}$ International Conference on Construction In Developing Countries (ICCIDC-I). August 4-5, 2008, Karachi, Pakistan.

Boer, L. \& Telgen, J. (1998). Purchasing practice in Dutch municipalities. International Journal of Purchasing and Materials Management, 34(1), 31-36.

Baron, R. M. \& Kenny, D. A. (1986). The moderator-mediator variable distinction in social psychological research: Conceptual, strategic, and statistical considerations. Journal of Personality and Social Psychology, 51(6), 1173.

Cornalba, C. \& Giudici, P. (2004). Statistical models for operational risk management. Physica A: Statistical Mechanics and Its Applications, 338(1), 166-172.

Frimpong, Y., Oluwoye, J., \& Crawford, L. (2003). Causes of delay and cost overruns in construction of groundwater projects in a developing countries; Ghana as a case study. International Journal of Project Management, 21(5),321-326.

Gelderman, C. J., Ghijsen, P. W. T., \& Brugman, M. J. (2006). Public procurement and EU tendering directives-explaining non-compliance. International Journal of 
Public Sector Management, 19(7), 702-714.

Hui, S. W., Radiah, O., Normah, H. O., Rashidah, A. R., \& Nurul, H. H. (2011). Procurement issues in Malaysia. International Journal of Public Sector Management, 24(6), 567-593.

Hayes, A. F. (2012). PROCESS: A versatile computational tool for observed variable mediation, moderation, and conditional process modeling [White paper] Retrieved from http://imaging mrc-cbu cam ac uk/statswiki/FAQ/SobelTest

Hayes, A. F. (2013). Introduction to mediation, moderation, and conditional process analysis: A regression-based approach. New York: Guilford Press.

Hayes, A. F., Preacher, K. J., \& Myers, T. A. (2011). Mediation and the estimation of indirect effects in political communication research. In E. Bucy \& R. Holbert (Eds.), Sourcebook for political communication research: Methods, measures, and analytical techniques (pp. 434-465). London: Routledge.

Hayes, A. F. (2009). Beyond Baron and Kenny: Statistical mediation analysis in the new millennium. Communication Monographs, 76(4), 408-420.

Inuwa, I. I. \& Diang'a, S. (2015). Effective procurement practices in a developing economy for sustainable construction. Journal of Environmental Technology, 8(2),64-78.

Jibrin, M. S., Ejura, S. B., \& Augustine, N. I. (2014). The public procurement reforms in Nigeria: Implementation and compliance challenges. Journal of Asian Business Strategy, 4(11), 149-162.

Krejcie, R. V. \& Morgan, D. W. (1970). Determining sample size for research activities. Educational and Psychological Measurement, 30(3), 607-610.

Kisang, L. \& Kwasira, J. (2015). Assessment of Success Factors for Implementation of Public Procurement and Disposal act in the County Government of Uasin Gishu, Kenya. International Journal of Economics, Commerce and Management, 3(11), 513-527.

Lazarides, T. (2011). Corporate governance legal and regulatory framework's effectiveness in Greece: A response. Journal of Financial Regulation and Compliance, 19(3), 244-253.

Mbaya, P. M. (2013). Factors influencing compliance with the public procurement legislation in Kenya (Masster thesis). University of Nairobi, Nairobi, Kenya.

MacKinnon, D. P., Lockwood, C. M., \& Williams, J. (2004). Confidence limits for the indirect effect: Distribution of the product and resampling methods. Multivariate Behavioral Research, 39(1), 99-128.

Othman, R., Zakaria, H., Nordin, N., Shahidan, Z., \& Jusoff, K. (2010). The Malaysian public procurement's prevalent system and its weaknesses. American Journal of Economics And Business Administration, 2(1), 6-11.

OECD (2007). Bribery in public procurement methods: Actors \& counter-measures. Massachusetts, USA: OECD Publishing. 
Abdullahi Nafiu Zadawa, Abdul Aziz Hussin, \& Atasya Osmad

The Mediating Effects of Awareness on The Relationship Between Procurement Manual Compliance's Barriers and Cost

Performance of Construction Projects

Ojo, E. \& Gbadebo, A. (2014). An assessment of non-compliance with procurement proceedings in procurement of works in Nigeria. International Journal of Economic and Business Management, 2(3):25-34.

Onyinkwa, J. (2013). Factors influencing compliance to procurement regulations in public secondary schools in Kenya: A case of Nyamache District, KisII County. Interdisciplinary Journal of Contemporary Research in Business, 5(1), 561.

Preacher, K. J. \& Hayes, A. F. (2008). Asymptotic and resampling strategies for assessing and comparing indirect effects in multiple mediator models. Behavior Research Methods, 40(3), 879-891.

Shehu, A. S. (2014, June). An overview of public procurement guidelines in Nigeria. Institute of Quantity Surveyors National Seminar 'Procurement of Construction Works and Services - Adapting to Contemporary Challenges'. June 11-12, 2014, Gombe, Nigeria.

Sang, W. K. \& Mugambi, F. (2014). Factors affecting compliance with public procurement laws and regulations in public institutions in Kenya: A case study on public entities in Mombasa County. International Journal of Social Sciences and Entrepreneurship, 1(11), 650-671.

Sekaran, U. \& Bougie, R. (2016). Research method for business: A skill building approach ( $7^{\text {th }}$ edition). New York: Wiley.

Williams-Elegbe, S. (2013). The World Bank's influence on procurement reform in Africa. African Journal of International and Comparative Law, 21(1), 95-119.

Wells, J. (2013). Corruption and collusion in construction: a view from the industry. In T. Soreide \& A. Williams (Eds.), Corruption, grabbing and development: Real world challenges (pp. 23-34). Cheltenham: Edward Elgar.

Zhao, X., Lynch, J. G., \& Chen, Q. (2010). Reconsidering Baron and Kenny: Myths and truths about mediation analysis. Journal of Consumer Research, 37(2), 197-206. 